\title{
Use of Schirmer strips and conjunctival swabs for virus detection on the ocular surface of adults: a scoping review
}

\section{Fitas de Schirmer e swab conjunctival para detecção de vírus na superfície ocular de adultos: scoping review}

\author{
Luís Expedito Sabage (D. Alessandra Mazzo,2, Josmar Sabage ${ }^{1,2,3}$, Taylor Endrigo Toscano Olivo', Carlos Ferreira Santos, \\ Luiz Fernando Manzoni Lourençone ${ }^{1,2}$ \\ 1. Faculdade de Odontologia de Bauru, Universidade de São Paulo, Bauru, SP, Brazil. \\ 2. Hospital de Reabilitação de Anomalias Craniofaciais, Universidade de São Paulo, Bauru, SP, Brazil. \\ 3. Instituto Lauro de Souza Lima, Bauru, SP, Brazil.
}

\begin{abstract}
Schirmer strips and conjunctival swabs are used in ophthalmology for the collection of tears and fluids. One of the biggest challenges during the COVID-19 pandemic has been accurate diagnosis and, in some cases, ocular manifestations are among the first symptoms. In this context, this study aimed to collect evidence to support the use of Schirmer strips and conjunctival swabs as a method of sample collection for viral analysis. A literature search was conducted following the Scoping Review protocol defined by The Joanna Briggs Institute. Studies were analyzed regarding virus research, collection methods, and sample analysis. The findings support that viruses can be detected on the ocular surface through analysis of Schirmer strips and conjunctival swabs. However, additional studies with larger samples and time data are necessary to confirm these conclusions.
\end{abstract}

Keywords: Antigen, surface/isolation \& purification; Conjunctiva; Tears; Eye protein/analysis; Specimen handling; Polymerase chain reaction/methods; COVID-19; Eye manifestations

RESUMO | A fita de Schirmer e o swab conjunctival são utilizados na oftalmologia como métodos de coleta para lágrimas e fluidos. Durante a pandemia da COVID-19, um dos desafios foi o diagnóstico correto e se sabe que, em alguns casos, as manifestações oculares podem ser um dos primeiros sintomas.

Submitted for publication: March 24, 2021

Accepted for publication: August 1, 2021

Funding: This study received no specific financial support.

Disclosure of potential conflicts of interest: None of the authors have any potential conflicts of interest to disclose.

Corresponding author: Luís Expedito Sabage.

E-mail: luis.sabage@usp.br
Nesse contexto, este estudo tem como objetivo levantar evidência que destaque o uso de fitas de Schirmer e de swabs conjuntivais como método de coleta para análise viral. Conduziu-se uma revisão de literatura seguindo o protocolo para Scoping Review definido pelo Joanna Briggs Institute. Os pesquisadores analisaram os estudos em busca do vírus pesquisado, os métodos de coleta e os métodos de análise. Vírus podem ser detectados na superfície ocular através da análise de fitas de Schirmer e de swabs conjuntivais, entretanto novos estudos com populações maiores e com definições claras de tempo são necessários para conclusões mais assertivas no tema.

Descritores: Antígeno de superfície/isolamento \& purificação; Túnica conjuntiva; Lágrimas; Proteína do olho/análise; Manejo de espécimes; Reação em cadeia da polimerase/métodos; COVID-19; Manifestações oculares

\section{INTRODUCTION}

Viruses are intracellular parasites that are the smallest known infectious agents. Although the mechanisms of viral disease are still not completely clear, there are several factors that directly contribute to viral tropism, such as viral receptors in the host cell, the specific cell line, and physical barriers that enable and/or inhibit infections. Once inside a cell, the virus may damage or destroy it through direct cytopathic effects, host antiviral immune responses, and/or transformations of the infected cells ${ }^{(1)}$.

The eye is a known site of viral infections, and viruses may appear in the intra- or extraocular space without visible systemic reverberation and affect multiple structures with variable manifestations ${ }^{(2,3)}$. Viral diagnosis is 
made based on clinical signs/symptoms and laboratory test results. Various laboratory tests are available with the specificity and sensitivity varying from one microorganism to another. Cell culture and analysis of genetic material from samples collected from blood, mucosa, or secretions are the main methods.

Based on clinical information and previous experience, the physician should decide between available diagnoses considering the patient's singularities. For the collection of samples from the eye, the most commonly used method is conjunctival swabs, although Schirmer strips have also shown good results.

\section{Current scenario}

Ever since the World Health Organization (WHO) declared COVID-19 a global pandemic, the academic community has concentrated its efforts to treat the pandemic and help people return to normal life. The Chinese and ophthalmologist Li Wenliang, MD, was the first to report on the novel catastrophic virus SARS-CoV-2. It is now known that ocular manifestations can be one of the first symptoms of COVID-19 and, consequently, the eye may contribute to the understanding of COVID-19 pathophysiology ${ }^{(4,5)}$. Although several studies on ocular manifestations of SARS-CoV-2 have been conducted, the virus collection methods and associations with the ocular surface were not clearly stated.

\section{Schirmer test}

The idea of collecting tears as a clinical test was first introduced in 1900 by Köster ${ }^{(6)}$. The test consists of the placement of filter paper on all extensions of the conjunctival sac while the nasal mucosa ies stimulated to produce tearing caused by nasal irritation. The objective of the test is to exhaust tear production to evaluate the function of lacrimal glands. As this test can take up to $90 \mathrm{~min}$ to perform, it is not viable for daily medical practice $^{(6)}$.

In 1903, Otto Schirmer, a German ophthalmologist, shortened the length of the paper strips and quantified tear production for 5 min using three methods, each of which analyzed a distinct tearing stimulation pathway: ocular and palpebral mucosa, nasal mucosa, and the retina $^{(6,7)}$. In the last century, several modifications have been made to the Schirmer test. Nevertheless, this test remains important in the quantification and standardization of tear volume. Currently, a filter paper strip measuring $60-\mathrm{mm}$ long and 5-mm wide is inserted at the temporal side of the conjunctival sac while the patient's eyes are closed. The strips are removed after $5 \mathrm{~min}$ and the wet part is measured. A result greater than $15 \mathrm{~mm}$ is considered to be normal, but the value varies with medication use, age, and the presence of chronic diseases ${ }^{(8,9)}$.

\section{Conjunctival swabs}

Conjunctival swabs are the most commonly used method for microbiological analysis because they allow the collection of cells and materials spread in the conjunctival sac instead of exclusively tears. One exception is in-office rapid antigen tests for adenovirus (AdV) because they are faster and present a good sensitivity and specificity of $89 \%$ and $94 \%$, respectively ${ }^{(10)}$. The method of collection is fast and simple: a swab with a cotton tip is gently passed using rotational movements on the conjunctival $\operatorname{sac}^{(11)}$. Topical anesthesia can be used to make the procedure more comfortable for the patient, since there is no significant difference in the final results when samples are analyzed by polymerase chain reaction (PCR) methods ${ }^{(12)}$. Proxymetacaine $0.5 \%$ is recommended for ocular surface anesthesia since it shows the fewest bactericidal effects among commercially available eye drops ${ }^{(13)}$. It is also recommended to use sterile swabs, since calcium-containing swabs can inhibit polymerase activity ${ }^{(14)}$.

In this context, this study aims to collect and evaluate scientific evidence of the use of Schirmer strips and conjunctival swabs as a method of virus collection on the ocular surface.

\section{METHODS}

A literature review was conducted according to The Joanna Briggs Institute (JBI) recommendations for scoping reviews ${ }^{(15)}$. All searches and publication access were completed in June 2020 and there was no restriction on article publication date. The guiding research question "Is it possible to detect a virus on the ocular surface with the Schirmer test and/or conjunctival swab?" was formed for the selection and search of the studies. This was built through the Population, Concept, and Context strategy. In this way, "P" was defined as adult patients (>18 years old), "C" as the Schirmer test and conjunctival swab, and the last " $\mathrm{C}$ " as all viruses.

For the literature search, the following descriptors, synonyms, and keywords were used: "adult patients," "Schirmer test," "conjunctival swab," and "virus." The Boolean operators AND, NOT, and OR were used between 
descriptors. The controlled descriptors were "adult patient(s)," "Schirmer test," "conjunctival swab(s)," and "virus." The uncontrolled descriptors were "adult(s)" OR "patient(s)," "Schirmer strip(s)," and "ocular virus" OR "viral infection." The search was performed using the databases PubMed, Web of Science, and Blibioteca Virtual em Saúde (BVS). Included articles were only those written in English, published in indexed sources, and with quantitative or qualitative approaches, primary studies, and reviews.

Insightful reading of the title, abstract, and keywords was performed to select the articles according to the previously established inclusion and exclusion criteria. When the title, abstract, and keywords were insufficient, the full text was also analyzed. All articles were called studies, enumerated in chronological order, and evaluated by three different researchers. Recommendations by JBI were adapted for the study singularities and used for data extraction. This article followed the Preferred Reporting Items for Systematic reviews and Meta-Analyses extension for Scoping Reviews (PRISMA-ScR) guidelines and checklist developed under EQUADOR (Enhancing the QUAlity and Transparency Of health Research) network guidance ${ }^{(16)}$.

\section{RESULTS}

Following the database search, 418 potential studies were identified. After reading the title, abstract, and keywords, 79 studies were selected. Of these, 27 articles were excluded because they were duplicate results. The full texts of the 52 remaining articles were read, and 16 were excluded for not answering the guiding question. Using the described methodology, the literature search identified 36 articles that met all criteria. This process is shown in figure 1 and the included studies are presented in table 1.

The three researchers analyzed all identified studies about virus research, collection methods, and sample analysis. Most of them were experimental or observational studies developed in the United Kingdom (7/36). Studies on the topic began in 1997 , but $55.6 \%$ were only published in the years 2011-2021.

Most studies were on $\operatorname{AdV}^{(17-29)}$ and Hesper Simplex Virus (HSV) ${ }^{(20,24,27,30-38)}$, followed by SARS-CoV-2 ${ }^{(38-46)}$. Varicella-Zoster virus (VZV) ${ }^{(30-32)}$, cytomegalovirus $(\mathrm{CMV})^{(31,32,47)}$, Epstein-Barr virus (EBV) ${ }^{(31,32)}$, Ebola $(\mathrm{EBO})^{(48,49)}$, human papillomavirus (HPV) ${ }^{(50)}$, and Zika virus ${ }^{(51)}$ have also been identified on the ocular surface. Enterovirus

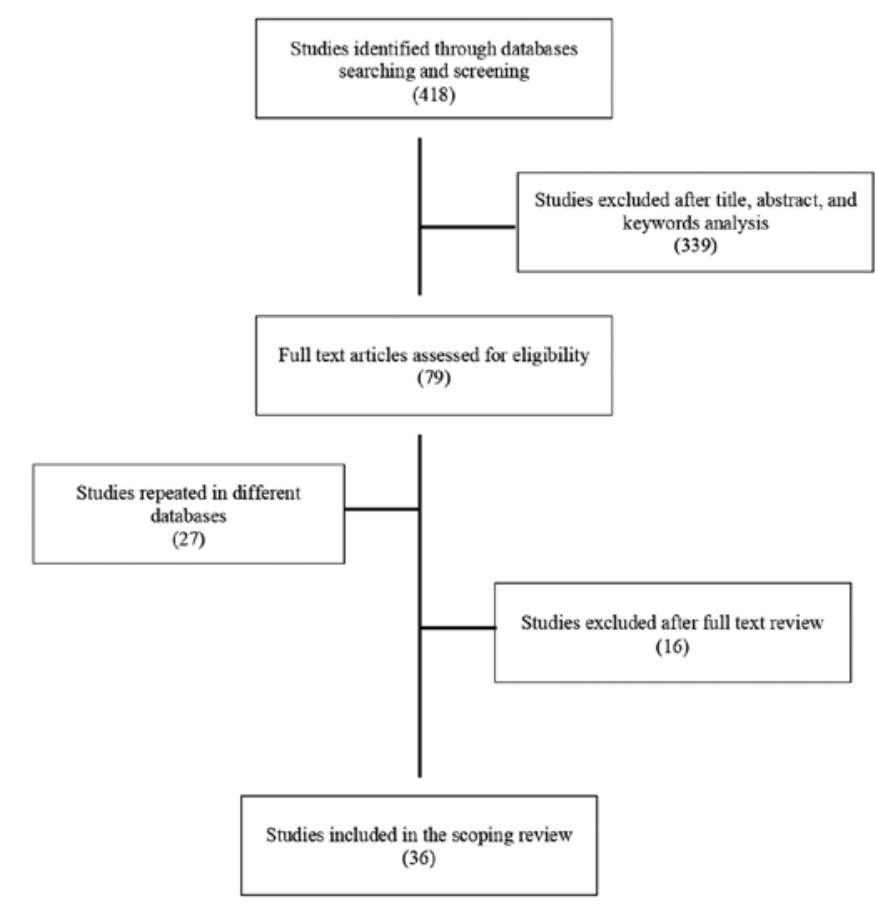

Figure 1. Summary of the systematic searches and processing of identified studies.

(EV), coxsackievirus A24 variant (CA24v), and SARS-CoV were not positive on ocular samples collected using conjunctival swabs or Schirmer strips ${ }^{(19,21,52)}$.

The preferred collection method was conjunctival swab alone in 29 out of 36 articles; six studies used Schirmer strips and only one study compared both collection methods ${ }^{(24)}$. One study was a narrative review about SARS-CoV-2 ${ }^{(44)}$. The majority of the samples were analyzed by PCR or reverse transcriptase-PCR (RT-PCR), with the exception of studies number $1^{(17)}$ and $17^{(33)}$ that used immunochromatography (IC) and enzyme immunoassay (EIA) and immunoblot analysis, respectively. Details of the methods and findings of the included studies are provided in table 2 .

\section{DISCUSSION}

Our literature search found that viruses can be identified on the ocular surface through analysis of conjunctival swabs or Schirmer strips. However, most studies have focused on AdV, HSV, and SARS-CoV-2, and other viruses have not been thoroughly investigated.

Studies focused on the detection of AdV and HSV were linearly developed over the last 20 years and 
Table 1. Identification and details of the included studies

\begin{tabular}{|c|c|c|c|c|}
\hline № & Year & Country & Purpose & Methodology \\
\hline $1^{(17)}$ & 1997 & Japan & Compare IC and ElA tests for AdV detection & Experimental Quantitative Study \\
\hline $2^{(18)}$ & 1997 & Germany & Evaluate type-specific primers for AdV & Experimental Quantitative Study \\
\hline $3^{(19)}$ & 1998 & India & Develop and evaluate nested PCR as a tool for detecting AdV from conjunctival swabs & Descriptive Observational Study \\
\hline $4^{(48)}$ & 1999 & USA & $\begin{array}{l}\text { Determine the genetic stability of EBO-Z, and whether additional strains } \\
\text { of EBO virus were circulating during Kikwit outbreak }\end{array}$ & Experimental Quantitative Study \\
\hline $5^{(47)}$ & 2000 & China & $\begin{array}{l}\text { Describe the application of conjunctival swab with PCR and virus } \\
\text { culture to confirm the diagnosis of CMV retinitis in AIDS patients }\end{array}$ & $\begin{array}{l}\text { Prospective Longitudinal } \\
\text { Quantitative Study }\end{array}$ \\
\hline $6^{(20)}$ & 2000 & UK & $\begin{array}{l}\text { Develop a multiplex PCR for the detection of AdV, HSV, } \\
\text { and Chlamydia trachomatis in conjunctival swabs }\end{array}$ & Experimental Quantitative Study \\
\hline $7^{(21)}$ & 2001 & Taiwan & $\begin{array}{l}\text { Evaluate the sensitivity and applicability of PCR and RT-PCR diagnoses } \\
\text { for keratoconjunctivitis associated with viral infection }\end{array}$ & Experimental Quantitative Study \\
\hline $8^{(30)}$ & 2001 & Netherlands & $\begin{array}{l}\text { Develop a longitudinal analysis of VZV DNA on the ocular surface } \\
\text { of patients with herpes zoster ophthalmicus }\end{array}$ & Experimental Quantitative Study \\
\hline $9^{(31)}$ & 2002 & UK & $\begin{array}{l}\text { Determine whether ocular shedding of EBV in the tear film is peculiar to patients with Sjogren's } \\
\text { syndrome, and whether coinfection with EBV occurs in the tear film }\end{array}$ & Experimental Quantitative Study \\
\hline $10^{(22)}$ & 2002 & Austria & Investigate a rapid and sensitive PCR-based assay for the detection of adenoviral infections & Experimental Quantitative Study \\
\hline $11^{(32)}$ & 2002 & France & $\begin{array}{l}\text { Use a multiplex PCR to detect herpes viruses in tears from normal } \\
\text { subjects and from patients with pathological conditions }\end{array}$ & $\begin{array}{l}\text { Descriptive Quantitative } \\
\text { Observational Study }\end{array}$ \\
\hline $12^{(52)}$ & 2004 & Singapore & $\begin{array}{l}\text { Determine the prevalence of virus in bodily excretions, } \\
\text { and time of seroconversion in discharged patients with SARS }\end{array}$ & Experimental Quantitative Study \\
\hline $13^{(23)}$ & 2004 & Brazil & Develop a rapid protocol to detect AdV in eye swab & $\begin{array}{l}\text { Descriptive Quantitative } \\
\text { Observational Study }\end{array}$ \\
\hline $14^{(24)}$ & 2005 & UK & Determine if AdV persists on the ocular surface following adenoviral conjunctivitis & Experimental Quantitative Study \\
\hline $15^{(25)}$ & 2007 & Japan & Establish a method of quantitative detection and rapid identification of AdV & Observational Quantitative Study \\
\hline $16^{(26)}$ & 2010 & China & $\begin{array}{l}\text { Test if high-density resequencing microarray can be applied to detection of viruses in } \\
\text { conjunctival swabs for patients with conjunctivitis }\end{array}$ & Experimental Quantitative Study \\
\hline $17^{(33)}$ & 2011 & Japan & Investigate if ICPO of HSV-1 is detectable in the tear fluid of patients with HEK & Observational Quantitative Study \\
\hline $18^{(34)}$ & 2013 & Korea & Analyze the methodological efficacy of the PCR assay for HSV-1 detection in tears & Experimental Quantitative Study \\
\hline $19^{(27)}$ & 2013 & UK & $\begin{array}{l}\text { Validate and introduce a simple boil extraction on dry swabs followed by amplification and real- } \\
\text { time detection using "in-house" assays for HSV and AdV with RNaseP as an internal control }\end{array}$ & Experimental Quantitative Study \\
\hline $20^{(35)}$ & 2014 & Spain & $\begin{array}{l}\text { Evaluate the usefulness of PCR as a rapid diagnostic method compared with the viral culture, and } \\
\text { to assess if conjunctival swabs samples were equivalent to corneal scrapings to diagnose of HK }\end{array}$ & Experimental Quantitative Study \\
\hline $21^{(28)}$ & 2015 & UK & Estimate the diagnostic accuracy of the AdenoPlus point-of-care AdV test compared to PCR & $\begin{array}{l}\text { Prospective Diagnostic Accuracy } \\
\text { Study }\end{array}$ \\
\hline $22^{(36)}$ & 2016 & Japan & Investigate diagnostic efficacy of PCR and ELISA for HSV in tears & $\begin{array}{l}\text { Nonrandomized Prospective Cross- } \\
\text { Sectional Study }\end{array}$ \\
\hline $23^{(29)}$ & 2016 & India & Identify and characterize the viral etiological agents associated with keratoconjunctivitis & Retrospective Observational Study \\
\hline $24^{(49)}$ & 2016 & UK & $\begin{array}{l}\text { Report EBO virus RT-PCR data for body site and fluid samples from a large cohort of EBO virus } \\
\text { survivors at clinic follow-up }\end{array}$ & Cross-Sectional Observational Study \\
\hline $25^{(51)}$ & 2017 & Singapore & Check if Zika virus could be detected in human tears after the first week of infection & Descriptive Observational Study \\
\hline $26^{(50)}$ & 2018 & Germany & Evaluate a non-invasive detection method for HPV in ophthalmic pterygia & $\begin{array}{l}\text { Observational Prospective Case } \\
\text { Control Study }\end{array}$ \\
\hline $27^{(37)}$ & 2019 & UK & Investigate the use of a corneal impression membrane for the detection of HSV-1 & Experimental Quantitative Study \\
\hline $28^{(39)}$ & 2020 & China & $\begin{array}{l}\text { Report the ocular characteristics and the presence of viral RNA of SARS-CoV- } 2 \text { in conjunctival } \\
\qquad \text { swab specimens in a patient with confirmed Covid-19 }\end{array}$ & $\begin{array}{l}\text { Prospective Observational Case } \\
\text { Study }\end{array}$ \\
\hline $29^{(38)}$ & 2020 & China & Detect SARS-CoV-2 in eye sample of one Covid-19 patient with obstruction of common lacrimal ducts & Prospective Observational Study \\
\hline $30^{(40)}$ & 2020 & India & Detect the presence of viral RNA of SARS-CoV-2 in conjunctival swab specimens of Covid-19 patients & Experimental Quantitative Study \\
\hline $31^{(41)}$ & 2020 & China & Describe the clinical spectrum of ocular symptoms and laboratory test in conjunctival swab samples & Cross-Sectional Study \\
\hline $32^{(42)}$ & 2020 & Canada & Present a case of Covid-19 with an initial medical presentation of keratoconjunctivitis & $\begin{array}{c}\text { Descriptive Observational Case } \\
\text { Study }\end{array}$ \\
\hline $33^{(44)}$ & 2020 & USA & Understand evidence about SARS-CoV-2 and ocular infection & Narrative Review \\
\hline $34^{(45)}$ & 2020 & China & Detect SARS-CoV-2 RNA in conjunctival swabs & Retrospective Observational Study \\
\hline $35^{(46)}$ & 2020 & France & Describe the multiplicity of ocular manifestations of Covid-19 patients & Descriptive Observational Study \\
\hline $36^{(43)}$ & 2021 & Spain & Evaluate the presence SARS-CoV-2 RNA in conjunctival swabs of Covid-19 patients & Cross-Sectional Study \\
\hline
\end{tabular}

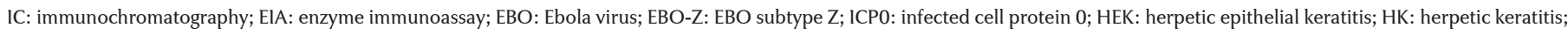
ELISA: enzyme-linked immunosorbent assay 
Table 2. Methodological details and main findings of the included studies

\begin{tabular}{|c|c|c|c|c|c|c|}
\hline № & Virus & Method of collection & Method of analysis & № of Patients recruited & № of Samples & Result (+ or - ) \\
\hline $1^{(17)}$ & $A d V$ & $\mathrm{CS}$ & IC and ElA & 130 & 130 & + \\
\hline $2^{(18)}$ & AdV & $\mathrm{CS}$ & PCR & 68 & 68 & + \\
\hline $3^{(19)}$ & $\mathrm{AdV} / \mathrm{EV} 70 / \mathrm{CA} 24 \mathrm{v}$ & CS & $\begin{array}{l}\text { Direct smear, PCR and } \\
\text { virus isolation }\end{array}$ & 20 & 20 & $+1-1-$ \\
\hline $4^{(48)}$ & $\mathrm{EBO}$ & $\mathrm{CS}$ & RT-PCR & 7 & 38 & + \\
\hline $5^{(47)}$ & CMV & $\mathrm{CS}$ & $\begin{array}{l}\text { Immunofluorescence and } \\
\text { PCR }\end{array}$ & 13 & 60 & + \\
\hline $6^{(20)}$ & $\mathrm{AdV} / \mathrm{HSV}$ & $\mathrm{CS}$ & PCR & 541 & 805 & $+/+$ \\
\hline $7^{(21)}$ & $\mathrm{AdV} / \mathrm{EV} 70 / \mathrm{CA} 24 \mathrm{v}$ & CS & $\begin{array}{l}\text { PCR, RT-PCR, culture } \\
\text { isolation, and } \\
\text { neutralization test }\end{array}$ & 113 & 113 & $+1-1-$ \\
\hline $8^{(30)}$ & VZV, HSV & $\mathrm{CS}$ & PCR & 21 & 246 & $+/-$ \\
\hline $9^{(31)}$ & EBV-1/EBV-2/CMV/VZV/HSV & ST & PCR & 54 & 54 & $+1+1-1-1-$ \\
\hline $10^{(22)}$ & $\mathrm{AdV}$ & $\mathrm{CS}$ & PCR & 15 & 15 & + \\
\hline $11^{(32)}$ & $\begin{array}{c}\mathrm{HSV}-1 / \mathrm{HSV}-2 / \mathrm{VZV} / \mathrm{CMV} / \\
\mathrm{EBV} / \mathrm{HHV}-6\end{array}$ & ST & PCR & 93 & 186 & $+/+/+1+1+1+$ \\
\hline $12^{(52)}$ & SARS-CoV & $\mathrm{CS}$ & PCR & 64 & 126 & - \\
\hline $13^{(23)}$ & $\mathrm{AdV}$ & CS & PCR & 7 & 7 & + \\
\hline $14^{(24)}$ & $\mathrm{AdV} / \mathrm{HSV}$ & ST and CS & PCR & 30 & 90 & $+1-$ \\
\hline $15^{(25)}$ & $\mathrm{AdV}$ & $\mathrm{CS}$ & PCR & 133 & 133 & + \\
\hline $16^{(26)}$ & $\mathrm{AdV}$ & $\mathrm{CS}$ & $\begin{array}{l}\text { High-density resequencing } \\
\text { microarray and PCR }\end{array}$ & 38 & 114 & + \\
\hline $17^{(33)}$ & $\mathrm{HSV}-1$ & ST & Immunoblot analysis & 18 & 18 & + \\
\hline $18^{(34)}$ & HSV & ST & PCR & 115 & 115 & + \\
\hline $19^{(27)}$ & HSV-1/HSV-2/AdV & CS & PCR & 541 & 541 & $+/+/+$ \\
\hline $20^{(35)}$ & HSV & $\mathrm{CS}$ & PCR & 188 & 188 & + \\
\hline $21^{(28)}$ & $\mathrm{AdV}$ & $\mathrm{CS}$ & PCR and point-of-care test & 109 & 109 & + \\
\hline $22^{(36)}$ & HSV & ST & PCR and ELISA & 82 & 82 & + \\
\hline $23^{(29)}$ & $\mathrm{AdV/EV}$ & $\mathrm{CS}$ & PCR and RT-PCR & 23 & 23 & $+1-$ \\
\hline $24^{(49)}$ & EBO & $\mathrm{CS}$ & RT-PCR & 112 & 92 & - \\
\hline $25^{(51)}$ & Zika virus & CS & RT-PCR & 29 & 58 & + \\
\hline $26^{(50)}$ & HPV & $\mathrm{CS}$ & PCR & 21 & 42 & + \\
\hline $27^{(37)}$ & HSV-1 & $\mathrm{CS}$ & PCR & 110 & 220 & + \\
\hline $28^{(39)}$ & SARS-CoV-2 & $\mathrm{CS}$ & RT-PCR & 1 & 8 & + \\
\hline $29^{(38)}$ & SARS-CoV-2/HSV-1 HHV-6B & $\mathrm{CS}$ & RT-PCR and PCR & 1 & 20 & $+/+/+$ \\
\hline $30^{(40)}$ & SARS-CoV-2 & $\mathrm{CS}$ & RT-PCR & 45 & 45 & + \\
\hline $31^{(42)}$ & SARS-CoV-2 & $\mathrm{CS}$ & RT-PCR & 2 & 4 & + \\
\hline $32^{(42)}$ & SARS-CoV-2 & $\mathrm{CS}$ & RT-PCR & 1 & 2 & + \\
\hline $33^{(44)}$ & SARS-CoV-2 & & & Narrative Review & & \\
\hline $34^{(45)}$ & SARS-CoV-2 & $\mathrm{CS}$ & RT-PCR & 33 & 66 & + \\
\hline $36^{(46)}$ & SARS-CoV-2 & $\mathrm{CS}$ & RT-PCR & 1 & 2 & + \\
\hline $33^{(43)}$ & SARS-CoV-2 & $\mathrm{CS}$ & RT-PCR & 36 & 72 & + \\
\hline
\end{tabular}

randomly conducted all over the world. In contrast, in 2020, scientists exponentially published studies on SARS-CoV-2 because the virus was first seen in the last days of 2019. During the first few months of 2020, the
WHO declared it a pandemic, and the world's research efforts were directed to overcoming this pandemic.

In contrast to SARS-CoV(52), SARS-CoV-2 RNA was found by RT-PCR in conjunctival swabs ${ }^{(38-46)}$. However, 
samples were collected from a few patients and only a low and varying percentage presented positive results and/or ocular symptoms ${ }^{(44)}$. Most of these studies were developed in China ${ }^{(38,39,41,45)}$, mainly because Chian was the first epicenter of the virus. In some cases, ocular manifestations are one of the first symptoms of COVID-19. As a result, some researchers believe that the eye may contribute to the understanding of COVID-19 pathophysiology ${ }^{(4,5)}$. Recent studies have proved the presence of angiotensin-converting enzyme 2 (ACE2) and transmembrane serine protease 2 (TMPSS2) in the conjunctiva, limbus, and cornea, with prominent staining in the superficial epithelium surface, which are key factors for SARS-CoV-2 infection in human cells ${ }^{(53)}$. These results support the necessity of ocular protection in preventing the spread of viruses.

Research on viral screening is, in most cases, correlated with external ocular symptoms with the purpose of solving clinical doubts about pathogenic agents and identifying methods for fast and accurate viral diagnosis. Studies on VZV, CMV, and EBV were mostly combined with HSV to determine coinfection and differential diagnosis ${ }^{(30-32)}$.

In contrast, only one study correlated viral detection on the ocular surface with intraocular symptoms. This study was published in 2000 and aimed to verify the efficacy of intravenous ganciclovir treatment in immunocompromised acquired immunodeficiency syndrome (AIDS) patients with CMV retinitis. The results showed high clinical relevance for confirming and differentiating diagnoses of CMV retinitis when ophthalmoscopic findings were determined by PCR methods of conjunctival swab samples ${ }^{(47)}$. No other studies on this topic were identified by this review, likely because the incidence of CMV retinitis in the AIDS population significantly decreased with the introduction of effective antiretroviral therapy and early accurate diagnosis ${ }^{(54-57)}$.

The most commonly used method for sample collection was conjunctival swabs. This method also collects conjunctival cells, while Schirmer strips only allow the collection of tears since fluids pass to the filter paper because of gravity, viscosity, and capillary flow dynamics -the same physical processes that explain how liquids impregnate porous materials differently ${ }^{(58,59)}$. Consequently, the collected samples represent two different materials: (1) tears, cells, and fluids dispersed in the conjunctival sac and tears and (2) substances dissolved in it.

In the identified studies, samples were typically analyzed by PCR or RT-PCR depending on the viral gene- tic material of DNA or RNA, respectively. PCR methods are widely used because they allow for the replication and detection of low loads of viral DNA/RNA ${ }^{(60)}$. The point-of-care test was also compared with PCR effectiveness, sensitivity, and specificity were high; however, this was only explored for $A d V^{(28)}$, likely due to epidemiological factors related to uncontrolled and fast spread of AdV conjunctivitis ${ }^{(61)}$.

This review included 36 articles from diverse countries and time periods, which suggests worldwide interest in the detection of viruses on the ocular surface in the last decades. The findings of this review may contribute to future research by clarifying key concepts to support the design of future research on ocular viruses.

Lastly, this review is subject to several limitations. First, only three databases were consulted. New articles on the theme are constantly being published, and so relevant studies may have been missed. Moreover, the analyzed studies typically involved a small number of patients and lacked clear definitions of collection time and viral persistence since disease onset. Additional studies with larger populations and time data are necessary to develop more definitive conclusions on this issue.

In conclusion, viruses can be detected through the analysis of samples collected by Schirmer strips and conjunctival swabs. Prior studies were generally conducted to understand viral infection, to develop accurate diagnostic methods, and to follow patients' responses to treatment.

\section{ACKNOWLEDGEMENTS}

This study was supported by São Paulo Research Foundation (FAPESP), Grant \#2020/07365-8.

\section{REFERENCES}

1. Summers WC. Virus infection. In: Encyclopedia of Microbiology. 2009:546-52. doi:10.1016/B978-012373944-5.00323-0

2. Nehemy M, Passos E. Oftalmologia na prática clínica. Belo Horizonte: Folium; 2015.

3. Pavan-Langston D. Ocular viral infections. Med Clin North Am. 1983;67(5):973-90.

4. Parke II DW. COVID-19 and Ophthalmology. EyeNet Mag [Internet]. March 2020. [cited 2020 jan 28]. Available from: COVID-19 and Ophthalmology - American Academy of Ophthalmology (aao.org)

5. Neri P, Lamperti M, Pichi F. SARS-CoV-2 and eye immunity: the lesson was learned but we are not done yet. Brainstorming on possible pathophysiology inspired by ocular models. Int Ophthalmol. 2020;40(8):1879-83.

6. Murube J. The Schirmer test: celebration of its first centenary. Ocul Surf. 2003;1(4):157-9. 
7. Schirmer O. Studien zur physiologie und pathologie der tränenabsonderung und tränenabfuhr. Graefe's Arch Ophthalmol. 1903;52(2):197-291.

8. Puderbach S, Stolze HH. Tear ferning and other lacrimal tests in normal persons of different ages. Int Ophthalmol. 1991;15(6):391-5.

9. Onyekwelu OM, Aribaba OT, Onyekwelu VI, Idowu OO, Salami $\mathrm{MO}$, Badmos KB, et al. Correlation between clinical and cytological parameters of dry eye among diabetics patients in a Nigerian tertiary hospital. Int Ophthalmol. 2020;40(8):2055-64.

10. Azari AA, Barney NP. Conjunctivitis: a systematic review of diagnosis and treatment. JAMA. 2013;310(16):1721-9. Erratum in: JAMA. 2014;311(1):95.

11. Wölfel R, Pfeffer M, Essbauer S, Nerkelun S, Dobler G. Evaluation of sampling technique and transport media for the diagnostics of adenoviral eye infections. Adenovirus sampling and transport. Graefes Arch Clin Exp Ophthalmol. 2006;244(11):1497-504.

12. Nogueira DC, Ueda SM, Murça MA, Hida WT, Felberg S, Serruya $\mathrm{L}$, et al. [Comparison of two transportation media for study of normal individual conjunctival microbiota]. Arq Bras Oftalmol. 2007;70(6):929-34. Portuguese.

13. Pelosini L, Treffene S, Hollick E). Antibacterial activity of preservative-free topical anesthetic drops in current use in ophthalmology departments. Cornea. 2009;28(1):58-61.

14. Salmon JF. Kanski's Clinical Ophthalmology. $9^{\text {th }}$ edition. London: Elsevier; 2020.

15. Peters MD, Godfrey CM, Khalil H, Mclnerney P, Parker D, Soares $\mathrm{CB}$. Guidance for conducting systematic scoping reviews. Int J Evid Based Healthc. 2015;13(3):141-6.

16. Tricco AC, Lillie E, Zarin W, O'Brien KK, Colquhoun H, Levac D, et al. PRISMA extension for scoping reviews (PRISMA-ScR): checklist and explanation. Ann Intern Med. 2018;169(7):467-73. Comment in: Ann Intern Med. 2018;169(7):502-3.

17. Uchio E, Aoki K, SaithoW, Itoh N, Ohno S. Rapid diagnosis of adenoviral conjunctivitis on conjunctival swabs by 10-minute immunochromatography. Ophthalmology. 1997;104(8):1294-9.

18. Pring-Akerblom P, Adrian T, Köstler T. PCR-based detection and typing of human adenoviruses in clinical samples. Res Virol. 1997;148(3):225-31.

19. Dalapathy S, Lily TK, Roy S, Madhavan HN. Development and use of nested polymerase chain reaction (PCR) for the detection of adenovirus from conjunctivitis specimens. J Clin Virol. 1998;11(1):77-84.

20. Elnifro EM, Cooper RJ, Klapper PE, Yeo AC, Tullo AB. Multiplex polymerase chain reaction for diagnosis of viral and chlamydial keratoconjunctivitis. Invest Ophthalmol Vis Sci. 2000;41(7):1818-22.

21. Chang $\mathrm{CH}$, Sheu MM, Lin $\mathrm{KH}$, Chen $\mathrm{CW}$. Hemorrhagic viral keratoconjunctivitis in Taiwan caused by Adenovirus types 19 and 37: applicability of polymerase chain reaction-restriction fragment length polymorphism in detecting adenovirus genotypes. Cornea. 2001;20(3):295-300.

22. Weitgasser U, Haller EM, El-Shabrawi Y. Evaluation of polymerase chain reaction for the detection of adenoviruses in conjunctival swab specimens using degenerate primers in comparison with direct immunofluorescence. Ophthalmologica. 2002;216(5):329-32.

23. Mendes RM, Nogueira ML, Marques JT, Pereira MV, Machado MA, Cunha AS, et al. A rapid polymerase chain reaction protocol to detect adenovirus in eye swabs. Arq Bras Oftalmol. 2004;67(3):423-7.

24. Kaye SB, Llyod M, Williams H, Yuen C, Scott JA, O’Donnell N, et al. Evidence for persistence of adenovirus in the tear film a decade following conjunctivitis. J Med Virol. 2005;77(2):227-31.
25. Miura-Ochiai R, Shimada Y, Konno T, Yamazaki S, Aoki K, Ohno S, et al. Quantitative detection and rapid identification of human adenoviruses. J Clin Microbiol. 2007;45(3):958-67.

26. Woo PC, Lao SK, Choi GK, Fung HT, Shek KC, Miao J, et al. Resequencing microarray for detection of human adenoviruses in patients with conjunctivitis. J Clin Virol. 2010;47(3):282-5. Comment in: J Clin Virol. 2010;47(3):387.

27. Moore C, Gatica L, Jones T, Mathews P, Watkins J, Tyson L, et al. Collect, boil and amplify - a simple approach for the detection of three common viruses associated with epidemic keratoconjunctivitis, conjunctivitis and dendritic ulcers. J Virol Methods. 2013;189(1):238-41.

28. Kam KY, Ong HS, Bunce C, Ogunbowale L, Verma S. Sensitivity and specificity of the AdenoPlus point-of-care system in detecting adenovirus in conjunctivitis patients at an ophthalmic emergency department: a diagnostic accuracy study. Br J Ophthalmol. 2015;99(9):1186-9.

29. Gopalkrishna V, Ganorkar NN, Patil PR. Identification and molecular characterization of adenovirus types (HAdV-8, HAdV-37, HAdV-4, HAdV-3) in a epidemic of keratoconjunctivitis occurred in Pune, Maharashtra, Western India. J Med Virol. 2016;88(12):2100-5.

30. Zaal MJ, Völker-Dieben HJ, Wienesen M, D'Amaro J, Kijlstra A. Longitudinal analysis of varicella-zoster virus DNA on the ocular surface associated with herpes zoster ophthalmicus. Am J Ophthalmol. 2001;131(1):25-9.

31. Willoughby CE, Baker K, Kaye SB, Carey P, O'Donnell N, Field A, et al. Epstein-barr virus (types 1 and 2) in the tear film in Sjogren's Syndrome and HIV infection. J Med Virol. 2002;68(3):378-83.

32. Robert PY, Traccard I, Adenis JP, Denis F, Ranger-Rogez S. Multiplex detection of herpesviruses in tear fluid using the "Stair Primers" PCR method: a prospective study of 93 patients. J Med Virol. 2002;66(4):506-11.

33. Morishige N, Yamada N, Morita Y, Nakamura Y, Nishida T, Sonoda $\mathrm{KH}$. Detection of ICP0 protein in tear fluid of individuals with active herpetic epithelial keratitis. Jpn J Ophthalmol. 2011;55(6):591-4.

34. Lee SY, Kim MJ, Kim MK, Wee WR. Comparative analysis of polymerase chain reaction assay for herpes simplex virus 1 detection in tear. Korean J Ophthalmol. 2013;27(5):316-21.

35. Barrado L, Suarez MJ, Pérez-Blázquez E, Otero JR, Folgueira MD. Could polymerase chain reaction test on conjunctival swabs be useful to diagnose herpetic keratitis? Enferm Infecc Microbiol Clin. 2014;32(1):28-30.

36. Shoji J, Sakimoto T, Inada N, Kamei Y, Matsubara M, Takamura E, et al. A diagnostic method for herpes simplex keratitis by simultaneous measurement of viral DNA and virus-specific secretory lgA in tears: an evaluation. Jpn J Ophthalmol. 2016;60(4):294-301.

37. Brunner M, Somerville T, Corless CE, Myneni J, Rajhbeharrysingh $\mathrm{T}$, Tiew S, et al. Use of a corneal impression membrane and PCR for the detection of herpes simplex virus type-1. J Med Microbiol. 2019;68(9):1324-9.

38. Hu Y, Chen T, Liu M, Zang L, Wang F, Zhao S, et al. Positive detection of SARS-CoV-2 combined HSV1 and HHV6B virus nucleic acid in tear and conjunctival secretions of a non-conjunctivitis COVID-19 patient with obstruction of common lacrimal duct. Acta Ophthalmol. 2020;98(8):859-63.

39. Chen L, Liu M, Zhang Z, Qiao K, Huang T, Chen M, et al. Ocular manifestations of a hospitalized patient with confirmed 2019 novel coronavirus disease. Br J Ophthalmol. 2020;104(6):748-51. Comment in: Br J Ophthalmol. 2020;104(6):741.

40. Kumar K, Prakash AA, Gangasagara SB, Rathod S, Ravi K, Rangaiah S, et al. Presence of viral RNA of SARS-CoV-2 in conjunctival swab specimens of COVID-19 patients. Indian J Ophthalmol. 2020;68(6):1015-7. Comment in: Indian J Ophthalmol. 2020;68(6):1018-9. 
41. Zhang X, Chen X, Chen L, Deng C, Zou X, Liu W, et al. The evidence of SARS-CoV-2 infection on ocular surface. Ocul Surf. 2020;18(3):360-2. Comment in: Travel Med Infect Dis. 2021;39:101955. Comment on: JAMA. 2020;323(11):1061-9.

42. Cheema M, Aghazadeh H, Nazarali S, Ting A, Hodges J, McFarlane $\mathrm{A}$, et al. Keratoconjunctivitis as the initial medical presentation of the novel coronavirus disease 2019 (COVID-19). Can J Ophthalmol. 2020;55(4):e125-e129. Comment in: Middle East Afr J Ophthalmol. 2020;27(1):1-3.

43. Güemes-Villahoz N, Burgos-Blasco B, Vilela AA, Arriola-Villalobos $P$, Rico-Luna CM, Cuiña-Sardiña R, et al. Detecting SARS-CoV-2 RNA in conjunctival secretions: is it a valuable diagnostic method of COVID-19?. J Med Virol. 2021;93(1):383-8.

44. Willcox MD, Walsh K, Nichols J), Morgan PB, Jones LW. The ocular surface, coronaviruses and COVID-19. Clin Exp Optom. 2020; 103(4):418-24.

45. Xie HT, Jiang SY, Xu KK, Liu X, Xu B, Wang L, et al. SARS-CoV-2 in the ocular surface of COVID-19 patients. Eye Vis (Lond). 2020;7:23.

46. Navel V, Chiambarretta F, Dutheil F. Haemorrhagic conjunctivitis with pseudomembranous related to SARS-CoV-2. Am J Ophthalmol Case Rep. 2020;19:100735.

47. Liu JH, Hsu WM, Wong WW, Wang J), Liu WT, Liu CY, et al. Using conjunctival swab with polymerase chain reaction to aid diagnosis of cytomegalovirus retinitis in AIDS patients. Ophthalmologica. 2000;214(2):126-30.

48. Rodriguez LL, De Roo A, Guimard Y, Trappier SG, Sanchez A, Bressler D, et al. Persistence and genetic stability of Ebola virus during the outbreak in Kikwit, Democratic Republic of the Congo, 1995. J Infect Dis. 1999;179(Suppl 1):S170-6.

49. Green E, Hunt L, Ross JC, Nissen NM, Curran T, Badhan A, et al. Viraemia and Ebola virus secretion in survivors of Ebola virus disease in Sierra Leone: a cross-sectional cohort study. Lancet Infect Dis. 2016;16(9):1052-6.

50. Chalkia AK, Derdas S, Bontzos G, Sourvinos G, Detorakis ET. Non-invasive detection of HPV DNA in exfoliative samples from ophthalmic pterygium: a feasibility study. Graefes Arch Clin Exp Ophthalmol. 2018;256(1):193-8.
51. Tan J], Balne PK, Leo YS, Tong L, Ng LF, Agrawal R. Persistence of Zika virus in conjunctival fluid of convalescence patients. Sci Rep. 2017;7(1):11194.

52. Leong HN, Chan KP, Khan AS, Oon L, Se-Thoe SY, Bai XL, et al. Virus-specific RNA and antibody from convalescent-phase SARS patients discharged from hospital. Emerg Infect Dis. 2004;10(10):1745-50.

53. Zhou L, Xu Z, Castiglione GM, Soiberman US, Eberhart CG, Duh EJ. ACE2 and TMPRSS2 are expressed on the human ocular surface, suggesting susceptibility to SARS-CoV-2 infection. Ocul Surf. 2020;18(4):536-44. Comment in: Ocul Surf. 2021;9:249-51.

54. Teoh SC, Wang PX, Wong EP. The epidemiology and incidence of cytomegalovirus retinitis in the HIV population in Singapore over 6 years. Invest Ophthalmol Vis Sci. 2012;53(12):7546-52.

55. Sugar EA, Jabs DA, Ahuja A, Thorne JE, Danis RP, Meinert CL; Studies of the Ocular Complications of AIDS Research Group. Incidence of cytomegalovirus retinitis in the era of highly active antiretroviral therapy. Am J Ophthalmol. 2012;153(6):1016-24.e5.

56. Alp NM, Baykam N, Kural G. Immune recovery uveitis associated with highly active antiretroviral therapy in a patient with CMV retinitis and AIDS despite a low CD4 $+\mathrm{T}$ cell count: case report and a review of the literature. Int Ophthalmol. 2010;30(2):183-9.

57. Heiden D, Tun N, Smithuis FN, Keenan JD, Oldenburfg CE, Holland $\mathrm{GN}$, et al. Active cytomegalovirus retinitis after the start of antiretroviral therapy. Br J Ophthalmol. 2019;103(2):157-60.

58. Washburn EW. The dynamics of capillary flow. Phys Rev. $1921 ; 17(3): 273-83$

59. Telles R, Li W, Dursch T), Lin MC, Radke C). Human tear-production rate from closed-eye Schirmer-strip capillary dynamics. aspects. Colloids Surf A: Physicochem Eng. 2017;521:61-8.

60. Bachman J. Reverse-transcription PCR (RT-PCR). Methods Enzymol. 20'13;530:67-74.

61. Garcia-Zalisnak D, Rapuano C, Sheppard JD, Davis AR. Adenovirus ocular infections: prevalence, pathology, pitfalls, and practical pointers. Eye Contact Lens. 2018;44 Suppl 1:S1-7. 